PROSE

\title{
Act of Kindness
}

\author{
Ayse Huseyin
}

\section{Homeless man}

\section{8:40am}

IT WAS THE sound of the train gliding across the rails that woke me in the morning; as the vibrations bounced off the walls and echoed through the old sewers. I wouldn't call it home, but rather a place where I seek refuge during the cooler nights of winter. The best thing about being homeless is that I can live anywhere I want without having to worry about bills or a mortgage. Only survival. Today was no different. I gathered what little I had: an empty water bottle, a handkerchief, an old book I'd found, a few odd socks and a photo of my beautiful wife, Kayla, and placed them into a garbage bag.

Gravel and broken glass crunched beneath my feet as I walked under a concrete overpass. As I followed the long and narrow path of the railway, the morning breeze blew discarded newspapers and plastic wrappers along the ground like tumbleweeds; while empty bottles and cans made hollow whistling sounds. As I looked ahead I began to calculate the distance I would need to travel in order to get to West Footscray Station. When I spotted a broken shopping trolley leaning against the banks of the railway tracks, I knew how much further I had to walk. Only another fifteen minutes. Just fifteen minutes to reach the platform and catch the next available train to North Melbourne. There has been word on the street that a new homeless shelter would 
open today. A shelter that would provide me with food and a place to rest my head for a least a couple of weeks, that's if I made it on time.

Finally I arrived at West Footscray Station, with five minutes to spare. Catching the train wasn't that difficult until they introduced Myki. I would find an old ticket on the ground, no use to anyone, but me. Now, I catch the train with the risk of getting caught and paying a fine with money that I don't have. I spent the remaining minutes searching the bin in hope that someone might have accidently thrown away their card or even the possibility of finding some loose change. While rummaging through the contents of the bin, I suddenly heard the lovely voice of a women announce, "The next train will be stopping at all stations except South Kensington," over the intercom. Within minutes I heard the rattling sound of carriages and saw the beaming lights of the train.

\section{Student \\ 9:00am}

I frantically searched through my handbag to ensure I had packed everything required for uni. Well, at least my photography class. Last time I forgot my camera and had to use my phone which was nowhere near the quality of my Canon. This time I had remembered to pack it. As the train drew to a halt, my attention was drawn outside. I caught a glimpse of a man by the side of the platform. I watched as he reached into a bin and pulled out what seemed to be a coffee cup. Casually, he flipped the lid off with a swift flick of his thumb and quickly drew it to his mouth. He didn't even look for what was inside. Half of me wanted to look away, embarrassed for him, while the other half was intrigued and fascinated to see what he would do next. I continued to watch as others looked past him, above him and below him so that their eyes wouldn't lock with his.

The man slowly walked towards the train and entered the same carriage as me. He stood for a while with his garbage bag of relics, and then took off his red knit beanie that almost covered his eyes. He ran his fingers through his hair and down the tip of his grizzly beard. He was tall with a thin build, maybe in his early to mid forties. He was neutral, trying not to bother anyone as his green eyes searched for a seat. 
I have always been fascinated by people. I often wonder what people are thinking, whether they always catch the train and where they are heading. Is he wondering what I am thinking? Is he aware that I am aware of him? There was only one way to find out. I took my heavy handbag off the seat beside me and wedged it between by feet. I looked at him, the seat, and then back at him. Slowly he made his way down the aisle and sat next to me. As we arrived at the next station the train suddenly stopped. We were informed that there would be a ten to fifteen minute delay due to roadwork up ahead. Everyone abruptly started complaining about the lack of service. One man shouted, "METRO, GET YOUR SHIT TOGETHER!" while other passengers quietly exchanged complaints with their neighbours. I could see that the man sitting next to me was becoming anxious. $\mathrm{He}$ began to fidget, eyes darting around. He was worried about something. "Hey, are you okay?"

But he did not respond. He was too busy staring off into the distance. I looked in the same direction and saw two ticket inspectors approaching our carriage. Then it clicked, he was searching the bin for a forgotten or abandoned Myki card, not something to drink. I wanted to help him. I had to think of something quick.

"Would you like a cup of coffee?"

For a second he froze like a statue. It was as if he had never been asked that question. Finally, he responded with a short nod. I smiled, handed him my Myki card then quickly got off the train and made my way to the small coffee stall on the platform.

\section{Homeless man}

\section{0:15am}

As she fled off the train the ticket inspector approached me. He looked at me and then the card I was now flicking in between my fingers. He gave me a hard stern look, then asked to see the card. My breathing became heavy. My stomach felt hollow as I anxiously awaited my fate. The card came clean. I closed my eyes in relief. I guess I was worried because I knew it wasn't mine. Once the officer left, the girl whose name I didn't know yet came back and took her seat by the window and handed me a cup of coffee. 


\section{Student}

\section{0:25am}

Following my arrival I handed him a cup of coffee while he tried to hand me back my card.

"You keep it. I'll get another one."

At first he hesitated then slowly put it in his pocket. After a while we started talking. He told me about his life and I told him a little bit about mine. He did most of the talking though; I figured he needed someone to talk to. He was lively and friendly. He even carried a conversation better than some. I felt as though he was almost out of place in the train full of sombre, frowning faces that were engaged with their electronic devices which left no room for social interaction.

"Sorry, I forgot to introduce myself. My name's Jess. Are you from Melbourne?"

He took a sip of coffee, "Yeah. Yeah, Melbourne is my home but I can live anywhere I want. Where are you from?"

"I'm from Geelong. Have you been there?"

He paused for a minute. As I waited for his response the train began moving again.

"A long time ago. I was there a long time ago before . . ." He stopped, rephrased his sentence and continued, "It wasn't always like this. I didn't live on the street. After I lost my wife I battled depression and had to quit my job. Since then I haven't been able to get back on my feet." He then took another mouthful of burning hot coffee. As he drew the cup back to his lap he caught sight of my camera.

"Are you a photographer?" he asked.

"No, not yet. It's still a dream at the moment. I still have another two years of uni. Do you like photos?"

"Yeah, I have a photo of my wife. Would you like to see it?"

"Of course."

He gently opened the black garbage bag that was clenched in his hand and pulled out a photo that had slightly worn edges. He looked at it, smiled and handed it to me. She had long, dark, wavy hair that past her shoulders, sparkling blue eyes and a smile that exposed the dimples in her cheeks.

"She's beautiful." 
"Yeah, she was."

As he retrieved the photo he paused for a moment, admiring the photo like he had just seen it for the first time.

"I used to live in Essendon with my wife until she was involved in a car accident that left her in a coma. Days, weeks, even months went by, nothing had changed. She was not responding to anything. The doctors told me I had to make a decision. I had to let her go. It was probably the most difficult decision I have ever had to make."

"I'm sorry," was all I could say.

The conversation never dragged. I wanted him to stay and chat more, but I could see he had somewhere to be. He smiled. It was the kind of smile you see when someone really wants to say something, but doesn't know how to do it right. "Thanks, for the coffee and the Myki." He turned to walk away, but stopped before he did, saying, "It was nice meeting you, Jess. Good luck with your dream." The doors slammed shut and the train began gliding along the rails. 